\title{
HEIDEGGER AND THE PHILOSOPHY OF LANGUAGE
}

\author{
WAYNE D. OWENS
}

University of Texas at San Antonio

Philosophical research will have to dispense with the "philosophy of language" if it is to inquire into "the things themselves" and attain the status of a problematic which has been cleared up conceptually. (Heidegger, Being and Time, pp. 209210.)

How curious, that stating is to be a laying. Do we intend with this reference to shake the foundation of all philology and philosophy of language, and to expose them as sham [Schein]? Indeed we do. (Heidegger, What Is Called Thinking?, p. 200.)

Two facts about Heidegger's published works invite an effort to understand and explain the negative opinion of the philosophy of language the undeveloped, critical remarks above indicate. First, there is not to be found in Heidegger's published works any systematic critique of philosophy of language as such. Second, despite the large number of his essays on language, it cannot be said that there is a developed Heideggarian philosophy of language, at least in any ordinary sense of that phrase. Such an attempt can be neither a mere exposition nor a simple derivation or deduction. It must rather be a restricted speculative construction, one that is alert to certain features of philosophy of language, on the one hand, and that does not violate either the letter or the spirit of Heidegger's thought, on the other. I shall attempt here such a constructive exploration of why Heidegger had the negative opinion of the philosophy of language the above quotations indicate.

I shall proceed by (1) sketching a general characterization of philosophy of language by focusing on what philosophers of language typically take as their subject matter, their typical means of access to it, and what they typically seek to accomplish; (2) in the spirit of Heidegger's thought, 
constructing an initial account of the limitations in these; (3) exploring the alternatives to them found in and suggested by Heidegger's later essays on language, (4) adding to (2) in light of (3); and (5) in light of these, offering a few general observations about the condition the philosophy of language is left in.

I.

Heidegger's negative opinion of the philosophy of language rests, I believe, not on the specific details of any particular philosophy of language but on certain typical orientations to language which prevade the whole domain and which have become basic, largely unquestioned assumptions in it. These typical orientations and unquestioned assumptions are what must be reviewed first. They must be reviewed with an eye toward what Heidegger's texts permit us to conclude to be the reasons behind his negative opinion, and they must be reviewed briefly.

One clear tendency among philosophers of language has been to objectify language, i.e., to base ideas about language in what appears when one looks at what has been or is imagined to be the speaking--broadly construed--of a particular language. In the phrase "philosophy of language," the "of" is ordinarily construed as an objective genitive. That is, language is taken as an already-constituted item or object to be interrogated philosophically. The means of access to the subject matter of the philosophy of language and the subject matter itself are inseparable. P. F. Strawson put it most succinctly when he wrote, "we understand nothing of human language unless we understand human speech."1

The prevailing ideas about language in the philosophy of language are almost always, if not exclusively, based on certain features of human speech. For example, since speaking is obviously a human activity, language must be a product of creative intellectual effort, a product of mind, or perhaps an example of constitutive rules of behavior.

'P. F. Strawson, "Meaning and Truth," in The Philosophy of Language, edited by A. P. Martinich (Oxford: Oxford University Press, 1985), p. 111. 
In order to think about language as it appears in speaking, a technical vocabulary--what 1 call, recognizing its deviance from common usage, a metalanguage-has been created. The metalanguage of the philosophy of language includes but is not limited to such words as: assertion, proposition, sentence, semantics, syntax, grammar, denotation, connotation, sense, reference, speech act, performative, constative, truth-value, etc.

What it means to interrogate language philosophically varies from philosopher to philosopher, but in the main it has meant formulating a general theory of language or of the features that all natural languages have in common. Formulating a general theory of language in turn has meant explaining language as it appears in actual or imagined acts of speaking in terms of (i.e., subordinating it to, assigning it to) something internal that externalizes itself in acts of speaking, something like constitutive rules of behavior, intentionality, mind, or intellect.

So, on one side of the "of" in "philosophy of language," there is language as objectified, actually or potentially comprehensible speech acts. On the other, there is philosophy as an attempt to explain theoretically this appearance of language in terms of other things or to formulate the features that all natural languages have in common.

It can of course be objected that the main interest or importance of philosophy of language is not merely reducible to speech act theory or philosophy of mind. It can be pointed outwith reference to Plato, Russell, and Quine, for example-that the main philosophical interest in language is ontological, meaning that language is a window onto or grip on the world, and that this explains the preoccupation with reference among philosophers of language.

We can summarize this brief characterization of the philosophy of language by saying that philosophers of language typically objectify language, that their objectification of it has necessitated a metalanguage, that their goal has been a theory of language, that certain features of human speech have become issues in philosophy of language,

${ }^{2}$ Cf., Jerrold J. Katz, The Philosophy of Language (New York: Harper \& Row, 1966), p.X. 
that philosophy of language has been subordinated to other "philosophical" domains, and that there is a possibility that philosophy of language is basically ontological. Let us assume that this characterization of the philosophy of langauge is widely, even if not universally, acceptable.

II.

Although Heidegger, as I have said, never articulated an explicit, detailed criticism of any philosophy of language, the spirit of his way of thinking allows for the construction of a Heideggerian critique of these basics of philosophy of language. To begin with, such a critique relates (1) to the subject matter itself (language), (2) to saying something about the subject matter, and (3) to the goals of the philosophers of language. There will be more later, after we review Heidegger's alternative approach.

Let us first be clear that there is no quarrel with the fact that in some respects language does lend itself to, even invites, objectification. Extant written texts and present and remembered instances of speaking and writing can surely be viewed as objects in a world of objects. Moreover, imagined variations on these, although not actually objects in the world, can be treated as if they were. But is there not always more, is there not always an excess, to language that does not come to view in such objectifying? Heidegger thought there is. In "The Age of the World Picture" he wrote, "Where anything that is has become an object of representing, it first incurs in a certain manner a loss of Being."3 To see the relevance of this quotation

${ }^{3}$ Martin Heidegger, The Question Concerning Technology and Other Essays, trans. William Lovitt (New York: Harper \& Row, Publishers, 1977), p. 142. Hereafter QT. In addition to this abbreviation, the following abbreviations will be used in the remainder of my paper:

BT: Martin Heidegger, Being and Time, trans. John Macquarrie and Edward Robinson (New York: Harper \& Row, 1962),

OTB: On Time and Being, trans. Joan Stambaugh (New York: Harper \& Row, Publishers, 1972),

OWL: Martin Heidegger, On the Way to Language, trans, Peter D. Hertz (New York: Harper \& Row, Publishers, 1971),

PLT: Martin Heidegger, Poetry, Language, Thought, trans. Albert Hofstadter (New York: Harper \& Row, Publishers, 1971), 
to his opinion of the philosophy of language, it is necessary to look into his opinion of thinking which objectifies.

In "Science and Reflection," Heidegger articulated what he took to be some limitations in thinking which objectifies, the sort of thinking he thought generally characteristic of the modern age and specifically characteristic of scientific ways of thinking. His articulation of its limitations rested on a distinction between what he called that which presences and the modern, scientific objectification of it, which he called Gegenstdndigkeit (objectness). He admitted that Gegenstandigkeit is a possible character belonging to that which presences, one produced when we. as he put it, "look attentively on the outward appearance wherein what presences becomes visible . . . (QT, p. 163). The distinctive feature of objectification and the one that produces objectness is this: "that which is to be grasped by the eye makes itself normative in knowing" (QT, p. 166). Only in terms of the Gegenstdndigkeit of that which presences is anything like theory possible.

Heidegger believed, however, that there is always more to that which presences than can be captured in objectification, more than its possible objectness manifests. About language, as something which presences, he wrote:

[It] holds sway as that which is not to be gotten around [and] that which, in the fullness of its coming to presence, they [the theoretical, objectifying sciences, including philosophy of language] can never encompass by means of their representing. (QT, pp. 175-76)

In "Science and Reflection" he did not elaborate on this remark. Perhaps he had something like the following in mind.

Objectification is limited by the viewing capacity of the observer. The myriad, ever-changing interests and concerns to which a particular language lends itself and the more than two thousand languages known, however, would in themselves seem to preclude a complete and total objectification of language

PT: Martin Heidegger, The Piety of Thinking, trans, James G. Hart and John C. Maraldo (Bloomington: Indiana University Press, 1975), WCT: What Is Called Thinking?, trans, J. Glenn Gray and F. Wieck (New York: Harper \& Row, Publishers, 1968). 
itself. Moreover, insofar as all language is historical, the objectification of language itself at any particular time imposes a stasis in an historically fluid phenomenon. The "loss of Being" incurred when it becomes the object of representing means restriction of a genuinely historical manifold to what has been spoken or imagined to have been spoken in a particular language, i.e., its external appearance at any given time. It cannot be uncritically assumed that such a restriction, implicit in the dominating reign of objectifying thinking, captures what is essential about language itself, since, as Heidegger put it, "objectness . . . remains only one kind of presencing, in which indeed that which presences can appear, but never absolutely must appear" (QT; p. 176).

We turn now to the prospects inherent in saying something about language. Speaking about language is a particular way of speaking a language. Speaking about language turns language on itself. As I mentioned above, to turn language on itself, philosophers of language have employed a metalanguage that includes words like: assertion, proposition, semantics, syntax, and truth-value. In the philosophy of language, the state of such a metalanguage at any given time is limited to and built upon the objectification of language, upon certain features of its external appearance in acts or imagined acts of speaking.

If, however, Gegenständigkeit (objectness) is only one way language's presencing can appear, then the metalanguage employed to speak about it can only reflect certain features of one way language's presencing can appear. At best, language can be only partially captured in the objectifying metalanguage of the philosophy of language. Since language, like everything else, remains ever more than can be totally objectified and ever more than any objectively oriented metalanguage can capture, the conclusion imposes itself that

the essential nature of language flatly refuses to express itself in words--in the language, that is, in which we make statements about language. If language everywhere withholds its nature in this sense, then such withholding is in the very nature of language. (OWL, p. 81) 
There remains something about language and about speaking a language that slips through the net of, that withholds itself from, the metalanguage of objectification--something that remains elusive, fugitive. And an even more brutal conclusion suggests itself: "we cannot know the nature of language-know it according to the traditional concept of knowledge defined in terms of cognition as representation ...." (OWL, p. 134).

We turn now in our initial review of the justification for Heidegger's negative opinion of the philosophy of language finally to the goals of philosophers of language. As 1 mentioned above, philosophers of language typically take as their goals the formulating of a general theory of language or of the features that all natural languages have in common. In practice this has meant explaining language, as objectified, in terms of intentionality, mind, intellect, constitutive rules of behavior, etc. That in terms of which language is explained is a function or product of how language is taken to appear in the first place. Since the subject matter of philosophy of language is language's external appearance in human speaking, certain characteristics of speaking are also associated with language, and philosophers of language find it easy to subordinate philosophy of language to philosophy of mind, philosophy of action, philosophy of man, etc., only because human speaking indicates presence of mind, is a human act, etc.

The problem with such a subordination relates to a problem with the way speaking and language are taken to be related to each other. We can think of it in terms of figure and ground. If we take speaking as the ground and language as the figure, as philosophers of language typically do, then it is reasonable to associate language with certain characteristics of speaking and to subordinate philosophy of language to or subsume it under philosophy of mind, philosophy of action, etc. Such a close association, even identification of language with certain characteristics of human speaking will, however, "never bring us to language as language" (PLT, p. 193). And if we have not been "brought" to language as language, how can any theory we formulate about it be taken seriously? Obviously it can't. Heidegger, as we shall see in the next section, seems to suggest that we should reverse the figure and ground relationship, i.e., take language as the ground and speech as the figure. Coming to terms with language as language will in fact demand it. 
So on the basis of Heidegger's general objections to the objective orientation of traditional philosophical thinking, including present-day philosophy of language, we have gained some initial insights into why he held the negative opinion of the philosophy of language the quotations with which we began indicate. In the briefest of terms, the problem is that philosophy of language has characteristically been reductive in a twofold manner. It has reduced language to its objective appearance in acts of speaking, and it has reduced philosophy of language to a branch of act theory or philosophy of mind or some other philosophical interest. It has focused on language as an externalization of something internal, as human activity, as rule governed behavior, as mirror of mind, etc., but not on language as language. To get beyond these initial insights, it will be necessary to look into certain salient features of Heidegger's mature reflections on language and to follow up on certain suggestions found in them.

III.

To acquire the right orientation into Heidegger's mature reflections on language, let us begin with a surprising fact that, taken on face value, might seem to nullify my whole effort: Heidegger was largely willing to admit the correctness of some of the prevailing views about language in the philosophy of language. "No one would dare to declare incorrect," he wrote, "let alone reject as useless, the identification of language as audible utterance of inner emotions, as human activity, as representation by image and by concept" (PLT, p. 193). This statement seems ironic, but it is not. Given his remarks about the dispensability of the philosophy of language and about its being a sham however, the question that it raises is, how can such views be correct?

To answer this question, it is necessary to clarify Heidegger's use of the word "correct." In his usage, correctness is a possible feature of judgmental assertion. It is a combination of representations (or words) in harmony (or agreement) with an object of judgment. Correctness therefore has a rightful place in the typical theoretical, epistemological practice of philosophy of language. And just as there was no quarrel with the fact that language lends itself to objectification, there is no argument with the fact that "the correct always fixes upon 
something pertinent in whatever is under consideration" (QT, p. 6).

But, for Heidegger, to say a philosophical assertion is correct is not the same as saying it is true: "the merely correct," he wrote, "is not yet the true" (QT, p. 6). Whereas correctness is a possible feature of judgmental epistemological assertion, "truth" in Heidegger's vocabulary concerns, among other things, the essence of that about which judgmental assertions are made. "Essence" ("Wesen"), however, did not have its usual, nominal meaning either. It did not mean the identifying characteristics of something already objectively present and identified. Rather, "essence" was taken in a verbal sense. Uncovering the essence of something meant bringing to sight the way or ways it reveals itself, comes to presence, and persists in presence. And, as Heidegger put it, "Only at the point where such an uncovering happens does the true come to pass [sich ereignet]" (QT, p. 6).

Heidegger's mature reflections on language were oriented not toward correct judgments about language as an object but toward an uncovering of the essence of language, its truth, i.e., the way or ways it reveals itself, comes to presence, and persists in presence. But how is such an uncovering to be accomplished? To answer this question, some prefatory methodological considerations are in order.

Despite his abandonment of phenomenology as a "school" of philosophy in favor of what he called das wesentliche Denken (essential thinking) and his general aversion to methodology, there are some respects in which Heidegger continued to practice the phenomenological method while abandoning many of the idealistic prejudices Husserl thought necessary for its deployment. Late in life, Heidegger could still write:

in what is most its own phenomenology is not a school. It is the possibility of thinking, at times changing and only thus persisting, of corresponding to the claim of what is to be thought. (OTB, p. 82)

Phenomenology as the thinking correspondence to what is to be thought is clearly demonstrated in his later essays on language. They evolved, at least in part, I believe, out of an aspiration to a radical phenomenological thinking experience with 
language, one that is missing in traditional philosophy of language.

There are at least two essential ingredients of the phenomenological method which are detectable, although not identified as such, in Heidegger's later essays on language: the move "to the things themselves" and a turn from objective, conceptual representation and judgment toward undergoing an experience (Erfahrung) with language. Together they support the contention that his thinking was phenomenological at least in spirit.

$\mathrm{Zu}$ der Sachen Selbst, To the things themselves, has been the motto of the phenomenological method from its beginning. As a thinking that goes to the things themselves, phenomenology is precisely not an assault upon them, an assault which hands them over to what they themselves are not, but rather an open, patient, personal meditation on them.

Heidegger wrote, "We do not wish to ground language in something else that is not language itself, nor do we wish to explain other things by means of language" (PLT, p. 191). Thus guided by the phenomenological motto, Heidegger recommended a return to our immediate personal experience with language and attempted to lead the way to where language can be seen from itself in the very way it shows itself from itself, to where its revealing itself, coming to presence, and persisting in presence shows itself. Such a procedure is not an intuition, an insight, a glance, or a discerning examination cast into an objective domain wherein the nominal, as opposed to the verbal, essence of language resides. Heidegger often cautioned against reading his own meditations on language as about language as an object. They were not intended to present knowledge of an object. Even so,

Whether the attempt to bring us face to face with the possibility of such an experience will succeed, and if it does, how far that possible success will go for each of us-that is not up to any of us. (OWL, p. 59)

In the case of language, going to the things themselves involves, paradoxically, a twofold holding-back. First, it is a bracketing (Husserl's word of course) or disengaging of all previous theories about language. Heidegger wrote, "To be sure, speaking is vocalization. Also, it can be considered a human 
activity. Both are correct views of language as speaking. Both will now be ignored" (OWL, p. 121). Holding-back in this way coincides with a turn to language itsclf and if successful opens the way to an unprejudiced experience with it. Second, holding-back is self-silencing, which is a cultivating of the possibility of undergoing an experience with language as such. Such a posture, it is hoped, will eventuate in what Heidegger at one time called authentic divination: "Authentic divination is the mode in which essentials come to us and so come to mind" (WCT, p. 207).

It is appropriate to ask, what does this twofold holdingback bring to mind? To answer this question, I shall digress somewhat from Heidegger's articulated thought but in a way that, I believe, will not violate its spirit and that ends up in the same place.

When we willfully silence ourselves, perhaps the first thing we notice is that there persists a silent, spontaneous, unsolicited occurrence or self-giving to consciousness of small fragments of language of varying degrees of complexity--bits of song, a commercial jingle, fragments of a previous or possible future conversation, pieces of a paper we are writing or hope to write, for example. In this rehearsal, this chaos, resides most of the raw material for all sorts and varieties of linguistic structures. And no matter how complex or elegant or creative the constructions out of this raw material may eventually become, they never completely leave behind these silent murmurings that are always already going on. Language gives itself even in the absence of an intention to communicate.

Let us now imagine that a need or desire to speak positions itself amidst this silent din. At least sometimes the chaos there spontaneously becomes orderly and a minor miracle takes place: something gets said, uttered, articulated.

There is no guarantee of course that linguistic order will occur out of this silent linguistic chaos. The presence of a motivation is a necessary but not a sufficient condition for speaking: language may or may not give itself to our need or desire to speak at the appropriate time. Speaking is possible only by virtue of the self-giving-the showing up, the coming to presence, the "speaking"-of language to our need or desire to speak. "Human speech," Heidegger wrote, ". . . is not selfsubsistent. The speech of mortals rests in its relation to the speaking of language" (PLT, p. 208). 
The next thing that presents itself in an unprejudiced experience with language concerns that which motivates the need or desire to speak, that in regard to which the silent chaos becomes structured and ordered. The motivation to speak is a particular way of being concerned with what shows itself in a general realm of self-showing and is conditioned and takes shape by what shows itself therein. This is, I take it, what Heidegger meant when he wrote, "all signs arise from a showing within whose realm and for whose purpose they can be signs" (OWL, p. 123. Cf., also, BT, pp. 204-05). Whereas there are other ways that things show themselves in the general realm of self-showing, the distinguishing feature of speaking language is that something capable of being spoken is explicitly identified as what it is. Moreover, that which speaking exalts from implicit presence to explicit appearance retains in itself aspects which do not come to explicit appearance in any particular linguistic event. Its being remains manifold. Even so, the fact that speaking brings something to explicit appearance can be demonstrated by observing that any subsequent response to what is spoken-whether is it clear or unclear, true or false, well-spoken or ill-spoken, referential or expressive, stupid, exaggerated, or what-not-presupposes that something is brought to appearance by and within it. But speaking can be that by which and within which something implicitly present makes an explicit, even if partial, appearance only if the language in it gives way or yields or surrenders itself to that which is brought to explicit appearance.

Thus a fourfold condition is necessary for a motivation to speak to come to fruition: an entity capable of speaking, the self-showing of an aspect from a manifold of aspects of something which prompts and shapes a motivation to speak, the presence of a motivation (a need or desire) to speak, and the self-giving, or showing up, of words which bring the relevant aspect of something merely present to explicitly identified appearance, words which deflect attention from themselves to what they show. In the absence of any of these, there is no overt linguistic event, nothing is said.

Heidegger attempted to zero in on the way language comes to presence, lends itself to the motivation to speak and to whatever is to be spoken, and persists in presence with the proposition, "The essential being of language is Saying as 
Showing." (OWL, p. 123. "Das Wesende der Sprache ist die Sage als die Zeige." All words emphasized in original.)

This last quotation must be interpreted in the right spirit. Prima facie it seems to contradict a previous quotation ("the essential nature of language flatly refuses to express itself in words--in the language, that is, in which we make statements about language.") and seems to be just another objectification of language. But it is neither a contradiction nor strictly an objectification. "Essential being" (Wesende) here is not nominal; it does not have to do with the whatness of something already disclosed. The quotation is not a judgmentalepistemological assertion. Rather, "essential being" has a fully verbal sense. Saying (Sage) refers to language's selfgiving, its coming to presence, to an entity capable of speaking. Showing (Zeige) is what it does when it gives itself, namely, it, as Heidegger put it, "summons from [all regions of presence] whatever is present to appear and to fade" (OWL, p. 124). So we can rewrite Heidegger's proposition, "the essential being of language is Saying as Showing," thus: in its self-giving, its coming to presence, language deflects attention from itself to that which it brings to explicitly identified appearance. In the immediacy of living linguistic experience, language, even when it gives itself, is also self-concealing, self-denying.

IV.

In light of this brief review of Heidegger's phenomenological attempt to lead the way to an immediate, personal, thinking experience with language and our extrapolations from it, it is now possible to elicit further insights in our attempt to understand his negative opinion of philosophy of language.

First, we have seen that the presence of a motivation--a need or desire--to speak is a necessary but not a sufficient condition for an overt linguistic event, that language may or may not give itself at the appropriate time to our need or desire to speak. This simple observation about our experience represents something more fundamental than the judgments that language is externalization of something internal, human activity, rule-governed form of behavior, mirror of mind, etc., because language's already having given itself is the condition for the possibility of any such judgments. Only because 
language at least sometimes gives itself to our motivation to speak is it possible ex post facto to make such judgments.

In particular, the identification of language as a product of human activity, while correct, seems rather impatient. Closer scrutiny shows that the presumption of the dominance of man over language is an inversion of the true relation: "Man," Heidegger wrote, "acts as though he were the shaper and master of language, while in fact language remains the master of man" (PLT, p. 215). He also wrote, "Mortals speak by responding to language in a twofold way, receiving and replying" (PLT, p. 209). In fact, the relation of dominance of language over man can perhaps best be experienced at those times when language does not give itself to our intentions to speak, when the right words for what we want to say do not come at the right time. At such times, according to Heidegger,

we leave unspoken what we have in mind and, without rightly giving it thought, undergo moments in which language itself has distantly and fleetingly touched us with its essential being. (OWL, p. 59)

There may of course be attempts to explain physiologically or psychologically the inability to find the right words for what we want to say: the presence or absence of a particular chemical, neurological event, or hormone, a "lapse" of memory or a frightening memory, for example. Phenomenologically, however, all such explanations are beside the point. What is experienced at such times is a refusal of language to give itself to our motivation to speak. We may concentrate diligently, but there is no guarantee that we will succeed. We can speak only when language gives itself to us. Heidegger himself claimed no privileged insight into the "mechanism" of the coming to presence of language. He asked, "How does the broken stillness come to sound in words? How does the broken stillness shape the mortal speech that sounds in verses and sentences?" His answer was this:

Assuming that thinking will succeed one day in answering these questions, it must be careful not to regard utterance, let alone expression, as the decisive element of human speech. (PLT, Pp. 20809) 
Second, Heidegger's phenomenology of language implies that philosophers of language who would base the philosophy of language on the philosophy of mind have the essential relationship between language and mind reversed. The phenomenological logic goes something like this. The selfshowing of what is thinkable must first be identified. Identification of that which presences can occur only if language gives the words which identify it. Whatever is to be thought (not to say imagined, not to say dealt with in praxis) therefore necessarily depends on the self-giving of language. That is, the self-giving of language is prior to the actuality of mind, not-as has often been assumed-the other way around.

Third, it was said earlier that the extent to which language can be captured in a metalanguage depends in part on the metalinguistic resources which have been devised for speaking about it. In light of the phenomenological fact that all speaking is contingent upon language's self-giving, it must be concluded that even the metalinguistic resources employed in forcing language to speak about itself are themselves given by language. Words for talking about language are adaptations of words which are already used to talk about something other than language. So the metalanguage of the philosophy of language, as well as all other sorts of attempts to talk about language, is derived from a more original self-giving of language, one originating in practical being in the world, where something other than language itself is an issue.

Fourth, a philosophy of language that takes already existing languages as a window onto or grip on already explicitly appearing things and then preoccupies itself with questions of reference is from the start based on a questionable assumption about how things in the world come to explicitly identified appearance in the first place. Heidegger's position was, as we have seen, that it is language that first brings something present to explicit appearance. The problem of reference therefore can be a problem only after language has first brought something to explicit appearance. A philosophy of language that takes language as re-presentation of something already appearing mistakes what is secondary and derivative (the question of reference) for what is primary and original. 
V.

This study has been governed by a modest ambition, namely, to understand and explain Heidegger's negative opinion of philosophy of language. His remarks about the dispensability of the philosophy of language and its being a sham were, it appears, directed mainly against a prevailing way of thinking about language in philosophy, one that makes language into an object of theoretical interest. They were not directed at any particular school of philosophy, but against any sort of thinking which can be characterized as an objectifying and theoretical approach to language. Linguistics, literary critics, psychologists, sociologists, etc., are drawn into the bounds of Heidegger's negative opinion insofar as they manifest such tendencies. On the other hand, anyone actively but non-objectively and non-theoretically engaged with language--poets and other literary artists, ordinary speakers, and philosophers other than philosophers of language, for example--escape them.

But, as we have seen, Heidegger went on to explore an alternative approach, one focusing on the personal experience anyone can have with language, one inviting us to pay attention to how we experience language ourselves. Such an approach radicalized reflection on language and yielded some rather unorthodox insights into the man-language relationship. It suggested that some of the basic, cherished ideas about the relationship typically assumed in the philosophy of language are backwards. For this reason alone, many philosophers are sure to consider his approach too unorthodox for "hard" philosophical studies. Could it not be however that "hard" philosophical studies, such as those manifest in contemporary philosophy of language, are insecurely grounded? It surely wouldn't be the first time in the history of philosophy that a radical approach did not share the conventions which have become normative.

It will perhaps have occurred as odd to some that no mention has been made here of such relevant Heideggerian themes as world and thing, dif-ference, Appropriation, expropriation, the question of Being, poetry, the Fourfold, time-space, the design of the being of language, etc. But their omission is easy to explain. Whereas such issues must be necessary ingredients in any systematic account of all 
Heidegger has said about language, they are not necessary for the more modest task of understanding and explaining his negative opinion of philosophy of language. For the latter purpose, a more selective reading of his works and following up on some of their suggestions are all that has been required.

One significant quotation, written in 1957, has thus far been avoided but should now be mentioned: "[T]he scientific and philosophical investigation of language and of languages . . . has its own particular justification and retains its importance" (OWL, p. 59). Sometime between 1952, when he wrote of exposing the philosophy of language as a sham, and 1957, Heidegger appears to have moderated somewhat his earlier negative opinion of philosophy of language. Nowhere did he explain what he thought the justification and importance of the scientific and philosophical investigation of language and of languages are. But it is clear that he was willing to admit some sort of justification and importance to them.

So in the end it cannot be said that Heidegger counseled total abandonment of philosophy of language. Perhaps he thought that such counsel would surely fall on deaf ears anyway, because, he perhaps thought, the objective, theoretical, epistemological drive for knowledge about language is so ingrained and strong that it cannot be thwarted at the present time. So, while recognizing some justification and importance in philosophy of language, he was compelled to go on and say, "But scientific and philosophical information about language is one thing; an experience we undergo with language is another" (OWL, p. 59). His phenomenology of language sought to bear witness to the fact that, as he put it, "Language is a primal phenomenon whose proprium is not amenable to factual proof but can be caught sight of only in an unprejudiced experience of language" (PT, p. 25).

In light of the foregoing account we must ask finally what, if anything, is the philosopher of language supposed to do? One thing might be to immediately forbear the ambition of a grand theory that would put all further questions about language to rest and spend some time on the questions: How does the broken stillness come to sound in words? How does the broken stillness shape the mortal speech that sounds in verses and sentences? Another might be to wait attentively for the appropriation of his or her speech from the silent depths from 
out of which it is given. Then perhaps he or she can say something heretofore unsaid about language.

Moreover, his phenomenology of language's coming to presence strongly suggests humility on the part of the philosopher of language and conscientiousness in avoiding mistaking how language shows itself and what it shows in any particular language at any particular time for the whole truth about language itself. It invites us to think: (1) that language is first and foremost a gift, something to be cherished and protected from debasement, (2) that the decisive fact about human spcech is not utterance or expression, but rather, the appropriating, self-giving of language, (3) that there is always more to be said about language as it continues to give itself, (4) that as long as language continues to give itself, never can everything be said about it, (5) that what we ordinarily take as language (speaking) emerges from a place that cannot be captured in objectifying statement, (6) that the nature of language qualifies as what can be called a mystery, and (7) that anything said about language should be taken as no more than a wave on the mysterious ocean of language itself. 